\title{
A new approach to comparing anti-CD20 antibodies: importance of the lipid rafts in their lytic efficiency
}

\author{
Mariam Hammadi \\ Jacques-Olivier Pers \\ Christian Berthou \\ Pierre Youinou \\ Anne Bordron \\ Centre Hospitalier Universitaire \\ EA22I 6 and IFR I48, Université de \\ Bretagne Occidentale and Université \\ Européenne de Bretagne, BP824, \\ 29609 Brest cedex, France
}

This article was published in the following Dove Press journal:

OncoTargets and Therapy

2 June 2010

Number of times this article has been viewed

\begin{abstract}
The view that B lymphocytes are pathogenic in diverse pathological settings is supported by the efficacy of B-cell-ablative therapy in lymphoproliferative disorders, autoimmune diseases and graft rejection. Anti-B-cell antibodies (Abs) directed against CD20 have therefore been generated, and of these, rituximab was the first anti-CD20 monoclonal Ab (mAb) to be applied. Rituximab-mediated apoptosis, complement-dependent cytotoxicity and Ab-dependent cellular cytotoxicity differ from one disease to another, and, for the same disease, from one patient to another. This knowledge has prompted the development of new anti-CD20 mAbs in the hope of improving B-cell depletion. The inclusion of CD20/anti-CD20 complexes in large lipid rafts (LRs) enhances the results of some, but not all, anti-CD20 mAbs, and it may be possible to include smaller LRs. Lipid contents of membrane may be abnormal in malignant B-cells, and could explain resistance to treatment. The function of these mAbs and the importance of LRs warrant further investigation. A detailed understanding of them will increase results for B-cell depletion in lymphoproliferative diseases.
\end{abstract}

Keywords: anti-CD20 antibodies, lymphocyte B, lipid rafts, B-cell disorders

\section{Introduction}

B lymphocytes perform a variety of functions in the immune system. For example, they play a part in eradicating bacteria or viruses, and promote all antitumoral responses. ${ }^{1}$ They may, however, run the risk of upregulating immune reactions. In autoimmunity, there is sufficient evidence to justify investigating B lymphocytes not only as antibody $(\mathrm{Ab})$ producing cells at the end of the pathological sequence, but also in the early stages of pathophysiology. ${ }^{2}$ These negative effects of B lymphocytes may be seen in graft rejection, which is associated with the production of $\mathrm{Abs},{ }^{3}$ and in graft versus host $(\mathrm{GVH})$ disease following allogeneic hematopoietic stem cell transplantation. ${ }^{4}$ Moreover, there is anarchic proliferation of B lymphocytes in lymphoproliferative syndromes such as lymphomas ${ }^{5}$ and chronic lymphocytic leukemia (CLL). ${ }^{6}$ Not surprisingly, B-cell-ablative therapies have been proposed for B-cell non-Hodgkin's lymphoma (NHL), representing a major advance in its treatment. One of these therapies involves anti-CD20 monoclonal Abs (mAbs), which are directed against the CD20-expressing members of the B-cell lineage, from late pre-B-cells through mature B-cells. Rituximab (RTX) was the first mouse-human chimeric mAb to be approved by the Food and Drug Administration (FDA) for the treatment of relapsed, or refractory, low-grade NHL. ${ }^{7}$ RTX is now used in other malignant proliferations, ${ }^{8}$ and is approved by the FDA for the treatment of autoimmune diseases (AIDS) ${ }^{9}$ and the prevention of graft rejection. ${ }^{10}$ To summarize the current situation, over 500,000 patients (including children) have 
been treated with RTX, and the improved patient-reported outcomes and cost-effectiveness have led to the production of other anti-B-cell agents. As a consequence, humanized anti-CD20 Abs are currently being developed. ${ }^{11-14}$

The effectiveness of anti-CD20 mAbs for a given disease is variable, as reported in patients with NHL or CLL. ${ }^{15-18}$ Furthermore, their self-efficacy differs from one B-cell disease to another. In fact, compared to observations with lymphoma, RTX has been shown to be weak when used as a single agent in CLL. ${ }^{19,20}$ These data therefore suggest that the results could be affected by factors in B lymphocytes themselves. The present review endeavors to chronicle therapeutic indications of anti-CD20 mAbs in these malignancies, to analyze the mechanisms of their action and to distinguish extrinsic or intrinsic factors, particularly lipid rafts (LRs) that could possibly be modulating their activities.

\section{Diseases treated with rituximab Malignant B-cell diseases \\ Non-Hodgkin B-cell lymphoma}

Many clinical trials have been conducted as induction therapy for patients recently diagnosed with follicular lymphoma or who have suffered a relapse when RTX was used on its own, in combination with chemotherapy, or with other types of Abs. Generally speaking, these mAbs, or the related combination of drugs, prolong survival compared to chemotherapy alone. ${ }^{21}$ Other trials have tested the efficacy of RTX in Waldenström's macroglobulinemia (WM) and multiple myeloma. ${ }^{22}$ In fact, Demopoulos et al have claimed that combining RTX with other drugs is the most commonly used primary treatment for WM. ${ }^{23}$ Diffuse large B-cell lymphoma (DLBL), which accounts for approximately $40 \%$ of NHLs in adults, is a type of aggressive lymphoma with a diffuse growth pattern and a high-intermediate proliferation index. Combining RTX with chemotherapy represents a breakthrough in the treatment of malignancies, and could become the new standard therapy in elderly and young low-risk patients. ${ }^{24}$ In addition, treatment of Burkitt's lymphoma, marginal lymphoma and Hodgkin lymphoma with RTX is currently being investigated (Table 1).

Its success notwithstanding, around $50 \%$ of NHL patients resisted treatment with RTX in that they did not respond to it, or they suffered an early relapse of the original disease.

\section{Leukemias}

These disorders are, in fact, bone marrow (BM) diseases. As in previous papers, we show the results of treating CLL and acute lymphocytic leukemia (ALL) with RTX. Many clinical trials have been conducted on CLL, ${ }^{25}$ but the efficacy of RTX was weak compared to its effects with lymphoma. One explanation is that RTX reduces the membrane level of CD20 on CLL B-cells. This is reflected in the fact that fractionation of RTX into several low doses perpetuates the expression of CD20, and thereby prolongs the activity of the mAb. ${ }^{26,27}$ Finally, the results of combining RTX with chemotherapy in the treatment of ALL appear to be encouraging, with acceptable levels of toxicity (Table 1). ${ }^{28}$

\section{Autoimmune diseases}

\section{Autoimmune diseases where RTX is known to be efficient}

A pilot study, RTX in AID, was set up in 2000 for the treatment of immune thrombocytopenic purpura. Objective clinical responses were observed in $30 \%$ of cases $^{29}$ and the beneficial effect of RTX was confirmed in others. ${ }^{30,31}$ Furthermore, the use of RTX with methotrexate has been approved by the FDA for the treatment of rheumatoid arthritis (RA), as it relieves symptoms in adult patients with moderate to severe active RA where treatment with one or more anti-TNF drugs has failed. RTX was also tested in Sjögren's syndrome with interesting results, ${ }^{32}$ and in systemic lupus erythematosus (SLE) where reduced activity of the disease and a clinical response of $86 \%$ were reported in one series of patients. ${ }^{33,34}$ However, certain SLE

Table I Diseases treated by rituximab

\begin{tabular}{|c|c|c|c|c|c|c|c|c|c|c|c|c|c|c|c|c|c|c|c|}
\hline & \multicolumn{7}{|c|}{ Auto-immune diseases (AID) } & \multicolumn{4}{|c|}{ Stem cell or organ transplantation } & \multicolumn{4}{|c|}{ Non Hogkin Lymphomas } & \multirow[t]{2}{*}{ HL } & \multicolumn{3}{|c|}{ Leukemia } \\
\hline & ITP & RA & ss & SLE & MS & ANCA & $\begin{array}{l}\text { DM/ } \\
\text { PM }\end{array}$ & $\begin{array}{c}\text { Auto- } \\
\text { graft }\end{array}$ & $\begin{array}{l}\text { Allo- } \\
\text { graft }\end{array}$ & GVHD & $\begin{array}{l}\text { Renal } \\
\text { rejection }\end{array}$ & DLBL & MALT & FL & MCL & & ALL & CLL & HCL \\
\hline $\begin{array}{l}\text { Clinical } \\
\text { phase }\end{array}$ & $\begin{array}{l}\text { II } \\
\text { III }\end{array}$ & IV & $\begin{array}{l}\text { II } \\
\text { III }\end{array}$ & $\begin{array}{l}\text { III } \\
\text { IV }\end{array}$ & II & $\begin{array}{l}\text { II } \\
\text { III }\end{array}$ & "I & "I & $\begin{array}{c}\text { Pilotal } \\
\text { trial }\end{array}$ & I/III & "I & IIII & III & III & 1 & "I & II & "I & II \\
\hline
\end{tabular}

AID: ITP, Idiopathic thrombocytopenic purpura; RA, Rheumatiod, Arthritis; SS, Sjogren's syndrome; SLE, Systemic lupusErythematosus; MS, Multiple sclerosis; ANCA, Antineutrophil cytoplasmic antibodies; DM, dermatomyositis; PM, polymyositis; GVHD, graft versus-host disease.

Lymphomas: DLBL, diffuse large B cell lymphoma; MALT, Mucosa-associated lymphoid tissue lymphoma; MCL, Mantle cell lymphoama; FL, follicular lymphoma; HL, Hodgkin lymphoma.

Leukemia: ALL, actue lymphoblastic leukemia; CLL, chronic lymphocytic leukemia; HCL, Hairy cell leukemia. 
patients show only partial or brief B-cell depletion, while the clinical benefit, if any, is modest. ${ }^{35}$ This failure suggests that SLE results from altered B-cell sensitivity, or possibly a complement (C) dysfunction. ${ }^{36}$ Multiple sclerosis and antineutrophil cytoplasmic Abs-associated vasculitides have been studied for RTX efficiency, but controlled clinical trials have not yet been reported (Table 1). ${ }^{37,38}$

\section{AID suspected of answering Abs}

Finally, anecdotal cases of anti-CD20 B-cell depletion have been reported in autoimmune-hemolytic anemia, cryoglobulinemia, acquired factor VIII-inhibitor disease, glomerulonephritis, pemphigus vulgaris, systemic scleroderma, polymyositis and dermatomyositis. ${ }^{39-43}$ An ongoing phase-I trial is even treating inactive psoriasis with RTX. Intriguingly, however, a handful of case reports suggest that this B-cell ablative therapy may actually induce psoriasis. $^{44,45}$

\section{Graft rejection and graft versus host disease}

The pathogenic role of B lymphocytes was highlighted in renal, cardiac, liver or pancreas transplantation, justifying B-cell depletion with RTX. ${ }^{46-48}$ Allogeneic hematopoietic stem cell transplantation may induce acute or chronic destruction of the host by the donor's immune system. Whilst pathogenic mechanisms involved in these phenomena are not clearly understood, RTX therapy may be effective for some patients (Table 1). ${ }^{49}$

\section{Action mechanisms of rituximab Complement-dependent cytotoxicity}

$\mathrm{C}$ may be utilized by RTX, and C-dependent cytotoxicity (CDC) seems to be pivotal in the efficiency of RTX ${ }^{50}$ In fact, after RTX treatment, C deficiency or consumption is striking in patients with CLL, ${ }^{51-53}$ with the over expression of C inhibitors CD55 and CD59. ${ }^{18,22}$ Klepfish et al tried to enhance the activity of RTX in CLL by adding fresh frozen plasma in an attempt to correct the $\mathrm{C}$ imbalance. ${ }^{52}$ Moreover, resistance to RTX therapy in NHL was ascribed to CDC inefficiency, as polymorphisms in the $\mathrm{C} 1 \mathrm{qA}$ gene were affecting its clinical response and the duration of the response. ${ }^{54,55}$ Following treatment with RTX, the CD20 molecules are clustered in the LRs, concentrating $\mathrm{IgG} F \mathrm{~F}$ regions locally and therefore inducing fixation of C1q. The $\mathrm{C}$ molecule, $\mathrm{C} 3$, has been shown to vary in affinity for LRs by supplementing cholesterol in cellular membrane and by virtue of the hypersensitivity of CD55 to phospholipases. ${ }^{56,57}$

\section{Antibody-dependent cell-mediated cytotoxicity}

ADCC occurs when B-cells are killed by monocytes, macrophages, natural killer (NK) cells and neutrophils following the binding of RTX to the Fc region. Among the Fc-gamma

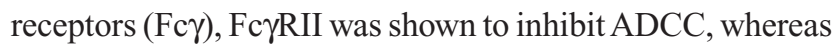
FC $\gamma R$ RIIIA behaved as an activator. However, a polymorphism of this latter receptor was also found to modulate ADCC. On the other hand, there is a dimorphism on residue 176 which can either be valine, with a high binding of IgG1, or phenylalanine with a low binding. ${ }^{58}$ Cartron et al confirmed that a homozygous valine 158 polymorphism of Fc $\gamma$ RIIIA leads to higher response rates and molecular complete remission rates in NHL patients after RTX treatment. ${ }^{59}$ However, in CLL, ADCC was not influenced by the Fc $\gamma R$ genotype expressed by autologous NK cells. ${ }^{17}$

\section{Apoptosis}

RTX-induced apoptosis requires translocation of CD20 into the LRs. ${ }^{60}$ This segregation increases cytosolic $\mathrm{Ca}^{2+}$ levels through association between CD20 and the B-cell receptor (BCR). ${ }^{61}$ Interaction between CD20 and raft membrane protein permits activation of components such as the phosphotyrosine kinases Lyn, Fyn, and Lck, as well as p75/80 (Cbp/PAG). This appears to be necessary for RTX, ${ }^{57}$ downstream signals mediated by the mitogen-activated protein kinase (MAPK) p38, cleavage of caspase-3, inhibition of Bcl-2, DNA fragmentation and, ultimately, apoptosis. ${ }^{62}$ Growth inhibition of NHL cell lines by RTX may be caused by externalization, location in LRs with CD20 and acid sphingomyelinase production through ceramide synthesis, which also activates MAPK. However, Chan et al demonstrated that, in several cell lines at least, redistribution of CD20 was not crucial. ${ }^{63}$

\section{Why is the efficacy of RTX variable? Is the quantity relevant?}

Number of lymphocytes

The efficacy of anti-CD20 mAb depends of the number of tumor cells. In fact, when the tumor burden is high, the various effector mechanisms engaged by RTX are saturated. ${ }^{19}$ Kennedy et al confirmed this observation through an analysis of elevated B CLL cell concentration binding by RTX, which led to complete consumption of $\mathrm{C}$ lytic activity and depletion of several $\mathrm{C}$ components. ${ }^{53}$ Their replacement with purified C proteins is sufficient to restore the cytotoxic activity of RTX. In aggressive DLBL, association between RTX and 
chemotherapy improves the rate and increases the duration of the response. ${ }^{64}$

\section{Other variables for a fixed number of B-cells Number of CD20 molecules}

CD20, a nonglycosylated phosphoprotein, is expressed in large quantities on the surface of almost all normal and malignant B-cells, up to 250,000 molecules per cell. However, resistance to RTX was identified in certain diseases, and especially in CLL. Mankai et al and others have established that this is related to a lower density of CD20 on B-cells in CLL compared to B-cells from other lymphomas, ${ }^{65}$ associated with a down-regulation of the purine-rich box-1 (PU.1) transcription factor, so that transfection of B-cells with its cDNA restores RTX-induced lysis. Similarly, stimulation of B-cells with $\mathrm{CpG}$ increases the expression of CD20 and ameliorates the CDC by RTX. ${ }^{66}$ The same results have been observed in lymphoma, ${ }^{20}$ but Weitzman et al claim that there was no correlation between ADCC and CD20 density. ${ }^{17}$

\section{Location of the B-cells}

After an infusion of RTX, circulating B-cells are rapidly removed. In contrast, germinal-center and marginal-zone B-cells resist this destruction. ${ }^{67}$ This phenomenon seems to be linked to factors such as BAFF (B-cell-activating factor) from the microenvironment, integrins and the lack of vascularization, rather than to poor tissue penetration by RTX. This factor is more decisive for RTX susceptibility than for the density of Fc $\gamma$ receptors on the membrane of all effectors. ${ }^{68}$ We can note that the level of BAFF in sera from patients with lymphoma may be a useful indicator in predicting the efficacy of treatment with RTX and chemotherapy. ${ }^{69}$ Furthermore, baseline serum levels of BAFF are inversely correlated with the induration of B-cell depletion after RTX treatment in primary Sjögren's syndrome. ${ }^{70}$ These findings provide new options for treating AID and hematological malignancies.

\section{Quality implication}

\section{Lipid rafts}

LRs have been described as stable structures, 100-500 nm in diameter, which resist extraction by nonionic detergents at low temperature due to their high cholesterol and glycosphingolipid content. ${ }^{71}$ This definition is misleading and may not apply to the composition of LRs in vivo. In fact, this structure is no longer accepted, and LRs are considered to be very heterogeneous, differing in the temporal stability of the composition of their lipids and proteins such as Src kinases.
The generally accepted definition of LRs was agreed at the 2006 Keystone symposium on LRs and cell function: "Lipid rafts are small (10-200 $\mathrm{nm}$ ), heterogeneous, highly dynamic, sterol- and sphingolipid-enriched domains that compartmentalize cellular processes". The largest components of LRs are glycosphingolipids such as ganglioside M1 (GM1), sphingomyelin (SM), cholesterol and phosphatidyl serine, the last three in approximately $50 \%$ greater quantities than in plasma membranes (Figure 1). "Small rafts can sometimes be stabilized to form larger platforms through protein-protein and protein-lipid interactions". ${ }^{72-74}$ When plasma membrane lipids and protein are clustered in the LRs, they can mediate transduction pathways which favor cellular adhesion, transmembrane signaling, virus budding, control of ionic pumps and channels, and mediation of vesicle fusion. ${ }^{75,65}$

Proteins connected to LRs have been described as insoluble in the nonionic detergent Triton X-100 at low temperature, in contrast to the other membrane lipids. ${ }^{70}$ This means we should be careful when investigating proteins linked to rafts, as analyses of fluorescence microscopy or fluorescence resonance energy transfer confirm these data. ${ }^{77}$ Many of these signaling proteins either reside in, or are transferred into, the LRs during signal transmission. Their fine-tuned regulation is probably influenced by nanoscale membrane microdomains, which are defined as dynamic and which apportion them to the membrane. ${ }^{78}$ These include CD20, ${ }^{79} \mathrm{BCR},{ }^{77}$ Fas, HLA II, ${ }^{80}$ TNF receptor, CD40, ${ }^{81}$ phosphatidyl inositol 3-kinase and several protein kinase $\mathrm{C}$ isoforms. $\mathrm{Cbp} / \mathrm{PAG}$, a ubiquitous, highly tyrosine-phosphorylated adaptor protein, only occurs in LRs, and plays an important part in the recruitment of Lyn, Fyn and Lck kinases into these LRs (Figure 1). ${ }^{82}$

Glycosphingolipids are involved in cell proliferation and differentiation. Glycosyl ceramides are the most widely distributed glycosphingolipids in cells, and act as precursors for the biosynthesis of many glycosphingolipids. GM1, widely used as a marker for LRs, is a sialoglycosphingolipid composed of a ceramide hydrophobic portion and a oligosaccharide sequence (Figure 2). It is integrated into the external leaf of the plasma membrane, and is at the forefront of the interaction of cells with their environment. For example, GM1 is known as a receptor for toxins and viral particles. ${ }^{83,84}$ Furthermore, close interaction between SM and cholesterol is necessary for LR formation, and sphingomyelinase can transform small LRs into large, ceramide-enriched ones. In addition, glycosphingolipids can be metabolized into lysosphingolipids and sphingoid bases. This function as a metabolite acts as second messenger in signal transduction pathways of growth and apoptosis..$^{85,86}$ 


\section{Outside}

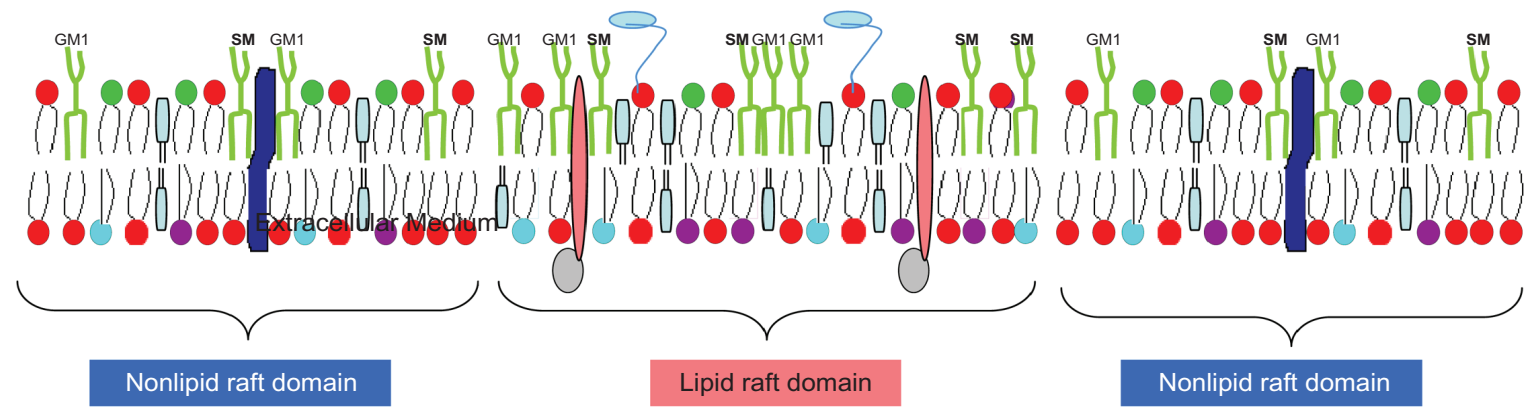

Inside

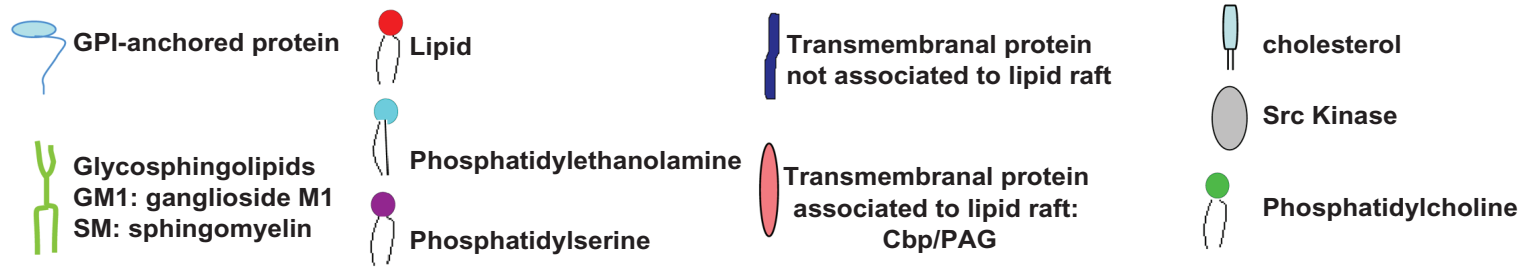

Figure I Lipid raft organization.
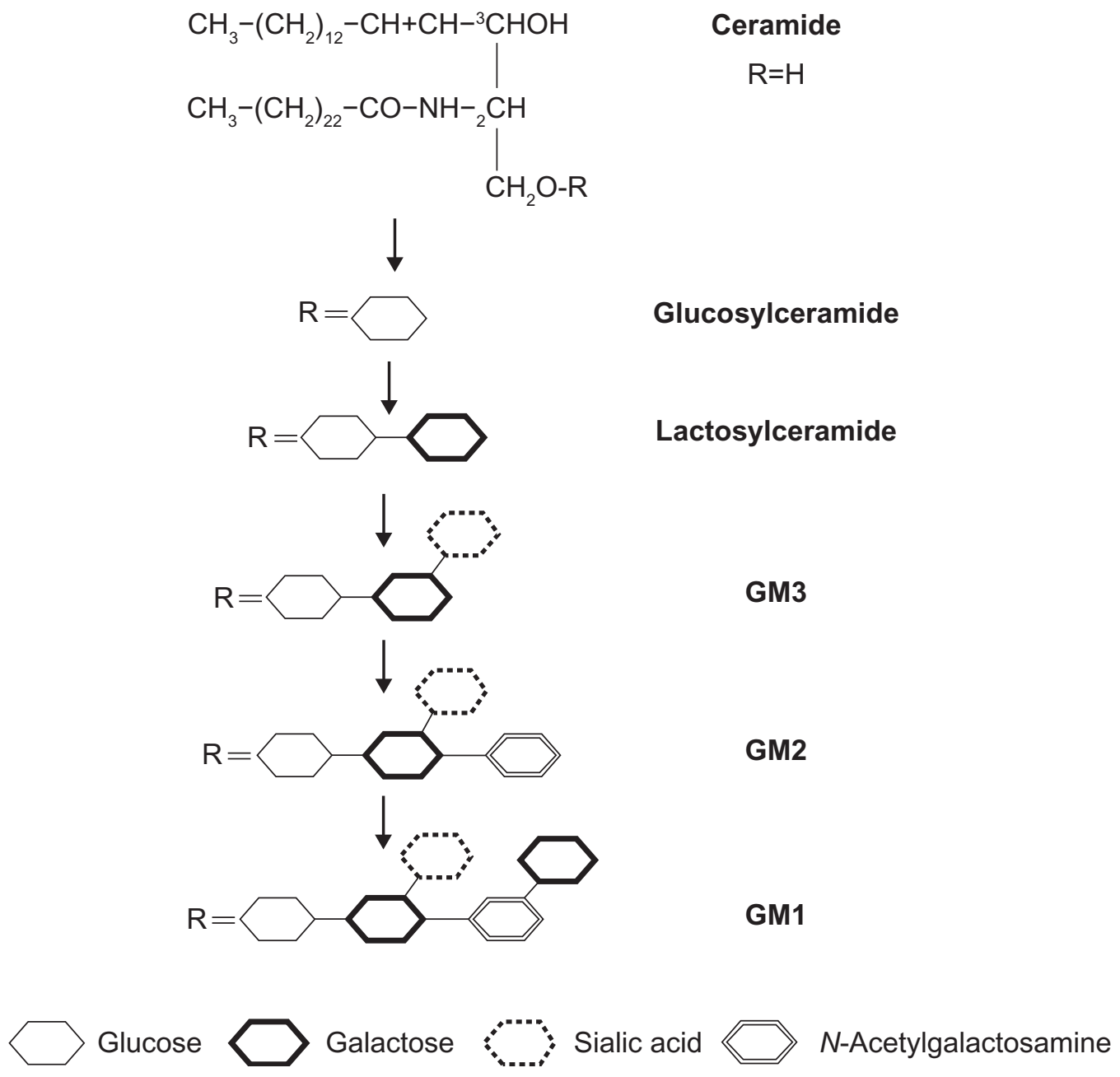

Figure 2 Synthesis of ganglioside GMI from ceramide. 


\section{Variation in their composition}

A recent study analyzing LR constitution in mantle cell lymphoma has revealed a downregulation of key LR proteins such as raftlin and Cbp/PAG. ${ }^{87}$ These are involved in B-cell transduction and in the pathology of lymphoma. Moreover, the presence of Cbp/PAG in the LRs is necessary for RTX to effect transmembrane signaling. ${ }^{57}$ The resistance of tumor B-cells to RTX may be explained by a deficiency in Cbp/ PAG. If we take this a step further, changes in the expression of a number of glycosphingolipids on the cell surface have been correlated with typical cancer phenotype and tumor progression. In this respect, GM1 expression differs between lymphoma subtypes, even within one lymphoma subgroup. A recent study has demonstrated a correlation between the expression of GM1 and response to RTX in NHL and CLL. ${ }^{88}$ In this latter leukemia, B lymphocyte membrane appears with increased fluidity, and produces lipid dynamics and lipid-protein interactions. ${ }^{89,90}$ Furthermore, glucosylceramide, lactosylceramide and SM improve activity of P-glycoprotein, a membrane efflux transporter, which frequently underlies cancer cell and bacterial resistance. ${ }^{91}$ There are excessive quantities of B lymphocytes in CLL patients. ${ }^{92,93}$ In addition, glucosylceramide synthase inhibitors stimulate CLL cells to react to conventional cytotoxic and cytostatic drugs used in treatment. $^{94}$

Finally, the disialoganglioside (GD3), a ganglioside weakly expressed in most normal tissues, is over-expressed during development and in pathological conditions such as cancer. It is responsible for a variety of events such as proliferation, differentiation and apoptosis. ${ }^{95}$ However, the relationship between ganglioside GD3 and CLL is not fully understood. It should be noted that alterations in the LR localization of certain signaling molecules contribute to the acuteness of B-cell-dependent autoimmune disease in some cases. On the other hand, the majority of SLE patients exhibited a low level of Lyn expression as well as a diminished association with LRs, due to an increase in ubiquitination through translocation of c-Cbl into LRs. ${ }^{96,97}$ This is associated with the abnormal expression of CD45, a membrane protein, tyrosine phosphatase, which controls Lyn expression by modulating its phosphorylation. ${ }^{98}$ Lyn serves as a negative regulator for B-cell signaling, and reduced negative signaling in LRs hyperactivates B-cells, leading to uncontrolled production of IL-10 and auto-Abs. The development of SLE induced by abnormalities in the sub-cellular localization of the BCR signaling pathway was confirmed by the discovery of a single polymorphism in the FcyRIIB gene. ${ }^{99}$ This mutation excludes Fc $\gamma$ RIIB from the LRs and impedes its inhibitory effects on BCR signals. ${ }^{100}$

\section{Efficacy of other anti-CD20 mAbs}

There is a clear need to develop new agents in order to improve the efficacy of B-cell depletion. In fact, there are many forms of resistance to RTX in autoimmune conditions and B-cell malignancies. On the other hand, other anti-CD20 mAbs have been, or are currently being developed (Table 2).

\section{CDC-improving anti-CD20 mAbs}

Ofatumumab (2F2, HuMax-CD20, Genmab/GSK) is a fullyhumanized, anti-CD20 mAb which binds to a portion closer to the B-cell membrane, and which is composed of the 74-80 amino acids in its small extracellular loop (Figure 3). Preclinical studies have thus far established that Ofatumumab has a slower rate of dissociation from CD20 than RTX and greater CDC power. Lysis of refractory RTX-resistant $\mathrm{B}$-cells is also effected through this $\mathrm{mAb},{ }^{50}$ with sustained success. ${ }^{14}$ Moreover, infusion reactions which appear after use of Ofatumumab are similar to those which appear with RTX, and it is more effective in CLL patients. ${ }^{101}$

Veltuzumab (IMMU-106, hA20, Nycomed/Immunomedics) is a humanized mAb with complementarity-determining regions (CDRs) identical to RTX, except at position 101 in the CDR3 of the variable heavy chain (VH) in aspartic acid substitutes for asparagines, and in framework regions of Epratuzumab, another humanized anti-CD22 Ab. This difference induces ADCC identical to that of RTX in CLL. ${ }^{17}$ There is a reduced off-rate ${ }^{102}$ and greater efficacy in lysing tumor cells in vitro by $\mathrm{CDC}$, and also in vivo with a phase I/ II for recurrent/refractory NHL. ${ }^{13}$

\section{ADCC-increasing anti CD20 mAbs}

Ocrelizumab (2H7) is a $90 \%-95 \%$ humanized $\mathrm{mAb}$ (Genentech/Roche/Biogen-Idec), and binds to an epitope which is different to that of RTX but which overlaps with it, and which is in the extracellular domain of CD20. ${ }^{103}$ Because C activation leads to side effects associated with RTX, a modification of its $\mathrm{Fc}$ portion is necessary. Its gives $\mathrm{mAb}$ a reduced $\mathrm{CDC}^{12}$ and increases its tolerability in autoimmune diseases. On the other hand, ADCC is higher than with RTX, due to amplified binding affinity for the low-affinity variants of FcyRIIIa.

Modifications to anti-CD20 Ab glycosylation, aimed at increasing ADCC, have generated three anti-CD20 mAbs. GA-101 is a humanized third-generation and glyco-engineered version of anti-CD20 mAb (Glycart Biotechnology AG, Genentech Inc, F Hoffmann-LaRoche Ltd, Biogen Idec Inc and Chugai Pharmaceutical Co Ltd) which produces greater ADCC, superior direct cell death and greater efficacy in depleting B-cells than RTX in the potential treatment of NHL or CLL. ${ }^{104}$ EMAB6 , with a low fucose content, triggers similar apoptosis and 
Table 2 Major characteristics of anti-CD20 antibodies compared to activity of rituximab

\begin{tabular}{|c|c|c|c|c|c|c|}
\hline & \multirow{2}{*}{$\begin{array}{l}\text { Antibody } \\
\text { Specificity }\end{array}$} & \multicolumn{5}{|c|}{ Mechanisms of action } \\
\hline & & $\mathrm{CDC}$ & $A D C C$ & Apoptosis & $\begin{array}{c}\text { B cell } \\
\text { depletion }\end{array}$ & $\begin{array}{l}\text { Very efficient in } \\
\text { B cells expressiong } \\
\text { low CD20 levels }\end{array}$ \\
\hline $\begin{array}{l}\text { Ofatumumab (2F2- } \\
\text { Genmab/GSK) }\end{array}$ & fully human IgG1 & +++ & & ++ & & + \\
\hline $\begin{array}{l}\text { Veltuzumab (IMMU-106, hA20- } \\
\text { Nycomed/Immunomedics) }\end{array}$ & humanized IgG1 & +++ & & ++ & ++ & \\
\hline $\begin{array}{c}\text { Ocrelizumab (2H7- } \\
\text { Genentech/Roche/Biogen-Idec) }\end{array}$ & humanized lgG1 & $+/-$ & ++ & + & & \\
\hline $\begin{array}{c}\text { GA-101 (Glycart Biotechnology } \\
\text { AG, Genentech/Roche) }\end{array}$ & humanized IgG1 & - & +++ & +++ & ++ & \\
\hline EMAB-6 (LFB) & $\begin{array}{l}\text { chimeric with low } \\
\text { fucose content }\end{array}$ & + & ++ & + & & + \\
\hline BLX-301 (Biolex/Argen) & humanized & & ++ & & ++ & \\
\hline $\begin{array}{c}\text { Experimental mAb 1,5,3 } \\
\text { (Amgen/Astrazeneca) }\end{array}$ & fully human & + & $\begin{array}{c}+ \\
++ \\
\text { (Fc } \gamma \text { RIIIa) }\end{array}$ & ++ & ++ & \\
\hline $\begin{array}{l}\text { Tositumomab (B1- } \\
\text { GlaxoSmithKline) }\end{array}$ & mouse $\lg G 2 a$ & - & $+/-$ & ++ & & \\
\hline
\end{tabular}

Abbreviations: $C D C$, complement-dependent cytotoxicity; ADCC, antibody-dependent cellular cytotoxicity.

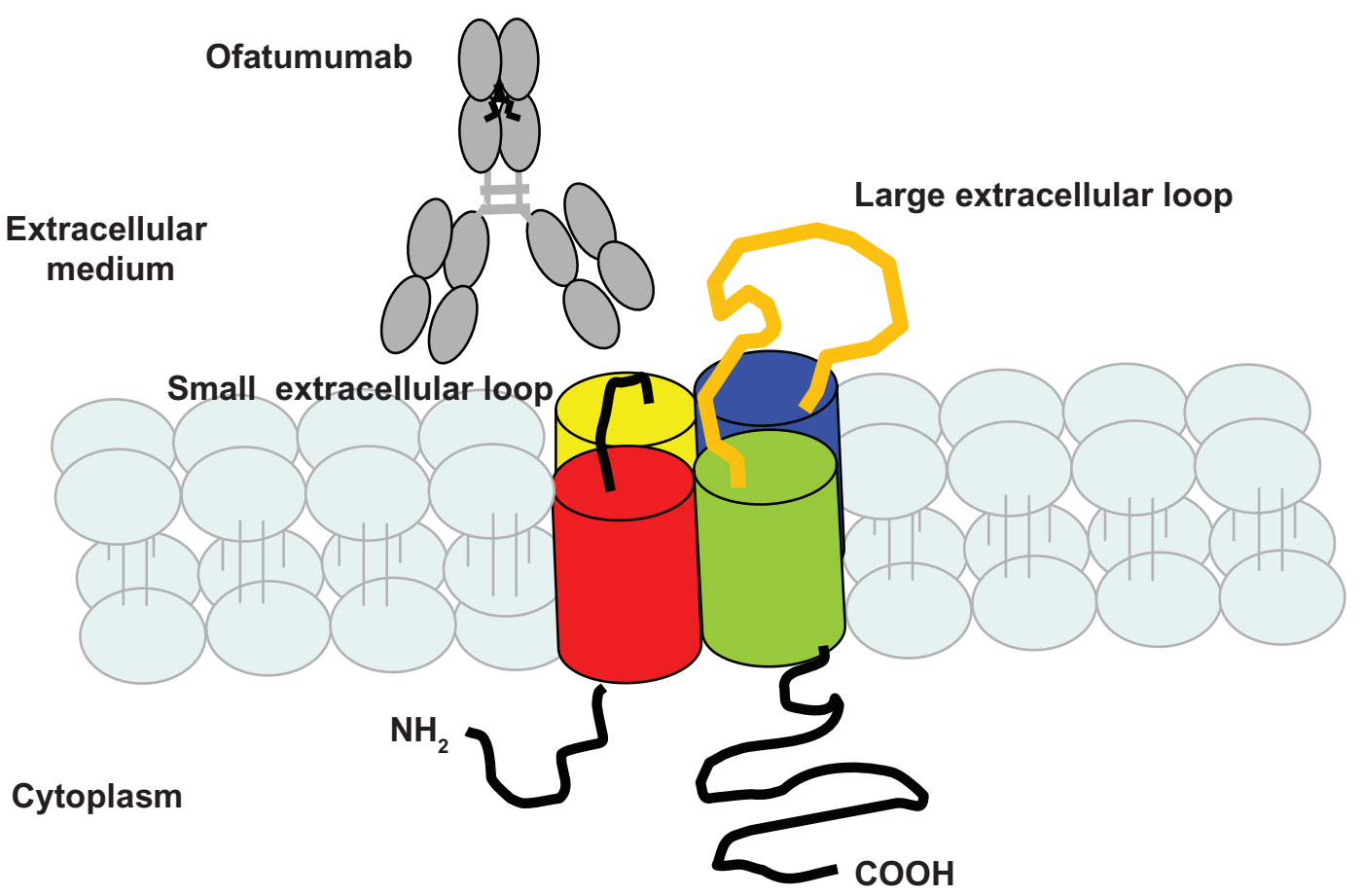

Figure 3 Fixation of ofatumumab on CD20 small extracellular loop. 
CDC to that observed for RTX, but promotes ADCC in CLL. The different levels of efficacy are more pronounced with low doses and when target cells express fewer CD20 molecules. ${ }^{105}$ BLX-301 (Biolex/Aragen) is a humanized anti-CD20 mAb with an optimized glycosylation structure, enhanced ADCC, potent B-cell depletion, and potentially low side effects. BLX-301 is being developed for treatment of NHL.

Finally, the objective of protein engineering is to manufacture an anti-CD20 Ab with greater potency and efficacy in all patients. Thus, vaccines are being developed with CD20 mimotope peptides $^{106}$ and AME-133v (Lilly), which improve the binding of anti$\mathrm{CD} 20 \mathrm{mAb}$ to the $\mathrm{Fc}$ receptor on their immune effectorcells.

\section{Anti-CD20 mAbs which increase programmed cell death}

Zevalin, an anti-CD20 mAb linked to Yttrium-90 (IDECY2B8, Ibritumomab Bayer Biogen Idec) and Bexxar (Tositumomab, B1 coupled to iodine I131-GlaxoSmithKline) were approved by the FDA in 2002 and 2003 respectively for treatment of NHL and for trials in other malignant diseases such as CLL. ${ }^{107}$ It is worthy of note that unradiolabeled tositumomab was described as inducing stronger apoptosis and ADCC than RTX. ${ }^{108}$

The Amgen/AstraZeneca mAb 1.5.3 better enhances proapoptotic activity in vitro than RTX, and mediates both CDC and ADCC, with superior ADCC when NK donor cells present an Fc $\gamma$ IIIa F/F allotype. In a primate pharmacodynamic model, this promotes higher B-cell depletion in lymph node organs and BM. ${ }^{109}$

The genetically-engineered tetravalent $\mathrm{Ab}$ (TetraMcAb), derived from the anti-CD20 mAb RTX and ofatumumab, exhibits more potent antiproliferative and apoptosis activities than ofatumumab or RTX. ${ }^{110}$ Hex-hA20, which comprises six Fabs with one Fc, translocates CD20 in LRs, affects ADCC but not CDC, and inhibits proliferation of NHL cell lines in vitro at low level concentration without requiring antibody cross-linking. ${ }^{111}$

\section{Conclusion}

The efficacy of anti-CD20 mAbs seems to depend, at least in part, on their ability to translocate CD20 molecules into LRs. Apoptosis is higher in those which cannot do so, where mAbs which can do so are characterized by CDC. ADCC is the same in both types. New anti-CD20 mAbs have been developed based on this classification. Mechanisms differ according to the type of B-cell-disease and the type of patient. These mAbs will be able to be used to best effect when their precise roles are known, and when B-cell-disorder physiopathology is better understood. For the time being, performance could be improved by increasing doses of mAbs, changing the type of mAb for each disease, associating different drugs simultaneously or successively, and modifying the LRs.

\section{Acknowledgments}

Work on this review was funded by grants from the "Conseil Régional de Bretagne", the "Ligue contre le Cancer" and the "Fédération Leucémie Espoir".

\section{Disclosure}

The authors report no conflicts of interest in this work.

\section{References}

1. Vollmers HP, Brändlein S. Natural antibodies and cancer. N Biotechnol. 2009;25(5):294-298.

2. Chan OT, Madaio MP, Shlomchik MJ. B cells are required for lupus nephritis in the polygenic, Fas-intact MRL model of systemic autoimmunity. J Immunol. 1999;163(7):3592-3596.

3. Xu H, He X, Sun J, Shi D, Zhu Y, Zhang X. The expression of B-cell activating factor belonging to tumor necrosis factor super family (BAFF) significantly correlated with C4D in kidney allograft rejection. Transplant Proc. 2009;41(1):112-116.

4. Cutler C, Miklos D, Kim HT, et al. Rituximab for steroid-refractory chronic graft-versus-host disease. Blood. 2006;108(2):756-762.

5. Martin B, Craig P, Grattan C, et al. Low-grade B-cell proliferation progressing to high-grade B-cell lymphoma. Am J Dermatopathol. 2009; 31(6):578-581.

6. Defoiche J, Debacq C, Asquith B, et al. Reduction of B cell turnover in chronic lymphocytic leukemia. Br J Haematol. 2008;143(2): 240-247.

7. Maloney DG, Grillo-López AJ, White CA, et al. IDEC-C2B8 (Rituximab) anti-CD20 monoclonal antibody therapy in patients with relapsed low-grade non-Hodgkin's lymphoma. Blood. 1997;90(6): 2188-2195.

8. Winkler U, Jensen M, Manzke O, Schulz H, Diehl V, Engert A. Cytokine-release syndrome in patients with B-cell chronic lymphocytic leukemia and high lymphocyte counts after treatment with an anti-CD20 monoclonal antibody (rituximab, IDEC-C2B8). Blood. 1999;94(7):2217-2224.

9. Pers JO, Devauchelle V, Daridon C, et al. BAFF-modulated repopulation of B lymphocytes in the blood and salivary glands of rituximabtreated patients with Sjögren's syndrome. Arthritis Rheum. 2007;56(5): 1464-1477.

10. Garrett HE Jr, Groshart K, Duvall-Seaman D, Combs D, Suggs R. Treatment of humoral rejection with rituximab. Ann Thorac Surg. 2002;74(4):1240-1242.

11. Cheson B. Bexxar (Corixa/GlaxoSmithKline). Curr Opin Investig Drugs. 2002;3(1):165-170.

12. Genovese MC, Kaine JL, Lowenstein MB, et al. Ocrelizumab, a humanized anti-CD20 monoclonal antibody, in the treatment of patients with rheumatoid arthritis: A phase I/II randomized, blinded, placebo-controlled, dose-ranging study. Arthritis Rheum. 2008;58(9): 2652-2661.

13. Morschhauser F, Leonard JP, Fayad L, et al. Humanized anti-CD20 antibody, veltuzumab, in refractory/recurrent non-Hodgkin's lymphoma: phase I/II results. J Clin Oncol. 2009;27(20):3346-3353.

14. Hagenbeek A, Gadeberg O, Johnson P, et al. First clinical use of ofatumumab, a novel fully human anti-CD20 monoclonal antibody in relapsed or refractory follicular lymphoma: results of a phase $1 / 2$ trial. Blood. 2008;111(12):5486-5495. 
15. Stolz C, Schuler M. Molecular mechanisms of resistance to Rituximab and pharmacologic strategies for its circumvention. Leuk Lymphoma. 2009;50(6):873-885.

16. Pawluczkowycz AW, Beurskens FJ, et al. Binding of submaximal $\mathrm{C} 1 \mathrm{q}$ promotes complement-dependent cytotoxicity (CDC) of B cells opsonized with anti-CD20 mAbs ofatumumab (OFA) or rituximab (RTX): considerably higher levels of CDC are induced by OFA than by RTX. J Immunol. 2009;183(1):749-758.

17. Weitzman J, Betancur M, Boissel L, Rabinowitz AP, Klein A, Klingemann H. Variable Contribution of Monoclonal Antibodies to ADCC in patients with chronic lymphocytic leukemia. Leuk Lymphoma. 2009;50(8):1361-1368.

18. Golay J, Zaffaroni L, Vaccari T, et al. Biologic response of B lymphoma cells to anti-CD20 monoclonal antibody rituximab in vitro: CD55 and CD59 regulate complement-mediated cell lysis. Blood. 2000; 95(12):3900-3908.

19. Glennie MJ, French RR, Cragg MS, Taylor RP. Mechanisms of killing by anti-CD20 monoclonal antibodies. Mol Immunol. 2007;44(16): 3823-3837.

20. Cvetković RS, Perry CM. Spotlight on rituximab in non-Hodgkin lymphoma and chronic lymphocytic leukemia. BioDrugs. 2006;20(4): 253-257.

21. Boland A, Bagust A, Hockenhull J, Davis H, Chu P, Dickson R. Rituximab for the treatment of relapsed or refractory stage III or IV follicular non-Hodgkin's lymphoma. Health Technol Assess. 2009; 13 Suppl 2:41-48.

22. Treon SP, Mitsiades C, Mitsiades N, et al. Tumor cell expression of CD59 is associated with resistance to CD20 serotherapy in patients with B-cell malignancies. J Immunother. 2001;24(3):263-271.

23. Dimopoulos MA, Kastritis E, Roussou M, et al. Rituximab-based treatments in Waldenström's macroglobulinemia. Clin Lymphoma Myeloma. 2009;9(1):59-61.

24. Sonet A, Bosly A. Rituximab and chemotherapy in diffuse large B-cell lymphoma. Expert Rev Anticancer Ther. 2009;9(6):719-726.

25. Christian BA, Lin TS. Antibody therapy for chronic lymphocytic leukemia. Semin Hematol. 2008;45(2):95-103.

26. Aue G, Lindorfer MA, Beum PV, et al. Fractionated subcutaneous Rituximab is well tolerated and preserves CD20 expression on tumor cells in patients with chronic lymphocytic leukemia. Haematologica 2010;95(9):329-332.

27. Williams ME, Densmore JJ, Pawluczkowycz AW, et al. Thrice-weekly low-dose rituximab decreases CD20 loss via shaving and promotes enhanced targeting in chronic lymphocytic leukemia. J Immunol. 2006; 177(10):7435-7443.

28. Griffin TC, Weitzman S, Weinstein H, et al. Children's Oncology Group. A study of rituximab and ifosfamide, carboplatin, and etoposide chemotherapy in children with recurrent/refractory B-cell (CD20+) nonHodgkin lymphoma and mature B-cell acute lymphoblastic leukemia: a report from the Children's Oncology Group. Pediatr Blood Cancer. 2009;52(2):177-181

29. Saleh MN, Gutheil J, Moore M, et al. A pilot study of the anti-CD20 monoclonal antibody rituximab in patients with refractory immune thrombocytopenia. Semin Oncol. 2000;27(6 Suppl 12):99-103.

30. Aggarwal A, Catlett JP. Rituximab: an anti-CD20 antibody for the treatment of chronic refractory immune thrombocytopenic purpura. South Med J. 2002;95(10):1209-1212.

31. Dierickx D, Verhoef G, Van Hoof A, et al. Rituximab in auto-immune haemolytic anaemia and immune thrombocytopenic purpura: a Belgian retrospective multicentric study. J Intern Med. 2009;266(5):484-491.

32. Devauchelle-Pensec V, Pennec Y, Morvan J, et al. Improvement of Sjögren's syndrome after two infusions of rituximab (anti-CD20). Arthritis Rheum. 2007;57(2):310-317.

33. Ding C, Foote S, Jones G.B-cell-targeted therapy for systemic lupus erythematosus: an update. BioDrugs. 2008;22(4):239-249.

34. Weide R, Heymanns J, Pandorf A, Köppler H. Successful long-term treatment of systemic lupus erythematosus with rituximab maintenance therapy. Lupus. 2003;12(10):779-782.
35. Leandro MJ, Cambridge G, Edwards JC, Ehrenstein MR, Isenberg DA. B-cell depletion in the treatment of patients with systemic lupus erythematosus: a longitudinal analysis of 24 patients. Rheumatology (Oxford). 2005;44(12):1542-1545.

36. Manderson AP, Botto M, Walport MJ. The role of complement in the development of systemic lupus erythematosus. Annu Rev Immunol. 2004;22:431-456.

37. Robak T. Ofatumumab, a human monoclonal antibody for lymphoid malignancies and autoimmune disorders. Curr Opin Mol Ther. 2008; 10(3):294-309.

38. Roccatello D, Baldovino S, Alpa M, et al. Effects of anti-CD20 monoclonal antibody as a rescue treatment for ANCA-associated idiopathic systemic vasculitis with or without overt renal involvement. Clin Exp Rheumatol. 2008;26(3 Suppl 49):S67-S71.

39. Berentsen S, Tjønnfjord GE, Brudevold R, et al. Favorable response to therapy with the anti-CD20 monoclonal antibody rituximab in primary chronic cold agglutinin disease. Br J Haematol. 2001;115(1): 79-83.

40. Field JJ, Fenske TS, Blinder MA. Rituximab for the treatment of patients with very high-titre acquired factor VIII inhibitors refractory to conventional chemotherapy. Haemophilia. 2007;13(1):46-50.

41. Collins M, Navaneethan SD, Chung M, et al. Rituximab treatment of fibrillary glomerulonephritis. Am J Kidney Dis. 2008;52(6):1158-1162.

42. Zambruno G, Borradori L. Rituximab immunotherapy in pemphigus: therapeutic effects beyond B-cell depletion. J Invest Dermatol. 2008; 128(12):2745-2747.

43. Cooper MA, Willingham DL, Brown DE, French AR, Shih FF, White AJ. Rituximab for the treatment of juvenile dermatomyositis: a report of four pediatric patients. Arthritis Rheum. 2007;56(9): 3107-3111.

44. Dass S, Vital EM, Emery P. Development of psoriasis after B cell depletion with rituximab. Arthritis Rheum. 2007;56(8):2715-2718.

45. Mielke F, Schneider-Obermeyer J, Dörner T. Onset of psoriasis with psoriatic arthropathy during rituximab treatment of non-Hodgkin lymphoma. Ann Rheum Dis. 2008;67(7):1056-1057.

46. Venetz JP, Pascual M. New treatments for acute humoral rejection of kidney allografts. Expert Opin Investig Drugs. 2007;16(5):625-633.

47. Billing H, Rieger S, Ovens J, et al. Successful treatment of chronic antibody-mediated rejection with IVIG and rituximab in pediatric renal transplant recipients. Transplantation. 2008;86(9):1214-1221.

48. Kessler L, Parissiadis A, Bayle F, et al. On behalf of the GRAGIL Study Group. Evidence for Humoral Rejection of a Pancreatic Islet Graft and Rescue with Rituximab and IV Immunoglobulin Therapy. Am J Transplant. 2009;9(8):1961-1966

49. Teshima T, Nagafuji K, Henzan H, et al. Rituximab for the treatment of corticosteroid-refractory chronic graft-versus-host disease. Int $J$ Hematol. 2009;90(2):253-260.

50. Beum PV, Lindorfer MA, Beurskens F, et al. Complement activation on B lymphocytes opsonized with rituximab or ofatumumab produces substantial changes in membrane structure preceding cell lysis. J Immunol. 2008;181(1):822-832.

51. van der Kolk LE, Grillo-López AJ, Baars JW, Hack CE, van Oers MH. Complement activation plays a key role in the side-effects of rituximab treatment. Br J Haematol. 2001;115(4):807-811.

52. Klepfish A, Gilles L, Ioannis K, Eliezer R, Ami S. Enhancing the action of rituximab in chronic lymphocytic leukemia by adding fresh frozen plasma: complement/rituximab interactions and clinical results in refractory CLL. Ann N Y Acad Sci. 2009;1173:865-873.

53. Kennedy AD, Beum PV, Solga MD, et al. Rituximab infusion promotes rapid complement depletion and acute CD20 loss in chronic lymphocytic leukemia. J Immunol. 2004;172(5):3280-3288.

54. Manches O, Lui G, Chaperot L, et al. In vitro mechanisms of action of rituximab on primary non-Hodgkin lymphomas. Blood. 2003;101(3): 949-954

55. Racila E, Link BK, Weng WK, et al. A polymorphism in the complement component $\mathrm{ClqA}$ correlates with prolonged response following rituximab therapy of follicular lymphoma. Clin Cancer Res. 2008;14(20): 6697-6703. 
56. Cohen AM, Shinitzky M. Modulation of complement lysis of human erythrocytes by the membrane lipid viscosity. Vox Sang. 1982;43(1): 23-27.

57. Semac I, Palomba C, Kulangara K, et al. Anti-CD20 therapeutic antibody rituximab modifies the functional organization of rafts/microdomains of B lymphoma cells. Cancer Res. 2003;63(2):534-540.

58. Wu J, Edberg JC, Redecha PB, et al. A novel polymorphism of FcgammaRIIIa (CD16) alters receptor function and predisposes to autoimmune disease. J Clin Invest. 1997;100(5):1059-1070.

59. Cartron G, Dacheux L, Salles G, et al. Therapeutic activity of humanized anti-CD20 monoclonal antibody and polymorphism in IgG Fc receptor FcgammaRIIIa gene. Blood. 2002;99(3):754-758.

60. Janas E, Priest R, Wilde JI, White JH, Malhotra R. Rituxan (anti-CD20 antibody)-induced translocation of CD20 into lipid rafts is crucial for calcium influx and apoptosis. Clin Exp Immunol. 2005;139(3):439-446.

61. Petrie RJ, Deans JP. Colocalization of the B cell receptor and CD20 followed by activation-dependent dissociation in distinct lipid rafts. J Immunol. 2002;169(2):2886-2891.

62. Pedersen IM, Buhl AM, Klausen P, Geisler $\mathrm{CH}$, Jurlander J. The chimeric anti-CD20 antibody rituximab induces apoptosis in B-cell chronic lymphocytic leukemia cells through a p38 mitogen activated protein-kinase-dependent mechanism. Blood. 2002;99(4):1314-1319.

63. Chan HT, Hughes D, French RR, et al. CD20-induced lymphoma cell death is independent of both caspases and its redistribution into triton X-100 insoluble membrane rafts. Cancer Res. 2003;63(17): $5480-5489$.

64. Feugier P, Van Hoof A, Sebban C, et al. Long-term results of the R-CHOP study in the treatment of elderly patients with diffuse large B-cell lymphoma: a study by the Groupe d'Etude des Lymphomes de l'Adulte. J Clin Oncol. 2005;23(18):4117-4126.

65. Mankaï A, Bordron A, Renaudineau Y, et al. Purine-rich box-1-mediated reduced expression of $\mathrm{CD} 20$ alters rituximab-induced lysis of chronic lymphocytic leukemia B cells. Cancer Res. 2008;68(18):7512-7519.

66. Mankaï A, Buhé V, Youinou P, Ghedira I, Berthou C, Bordron A. Improvement of rituximab efficiency in chronic lymphocytic leukemia by CpG-mediated up-regulation of CD20 expression independently of PU.1. Ann N Y Acad Sci. 2009;1173:721-728.

67. Gong Q, Ou Q, Ye S, et al. Importance of cellular microenvironment and circulatory dynamics in B cell immunotherapy. J Immunol. 2005; 174(2):817-826

68. Ahuja A, Shupe J, Dunn R, Kashgarian M, Kehry MR, Shlomchik MJ. Depletion of B cells in murine lupus: efficacy and resistance. J Immunol. 2007;179(5):3351-3361.

69. Kim SJ, Lee SJ, Choi IY, et al. Serum BAFF predicts prognosis better than APRIL in diffuse large B-cell lymphoma patients treated with rituximab plus CHOP chemotherapy. Eur J Haematol. 2008;81(3): $177-184$.

70. Pers JO, Devauchelle V, Daridon C, et al. BAFF-modulated repopulation of B lymphocytes in the blood and salivary glands of rituximab-treated patients with Sjögren's syndrome. Arthritis Rheum. 2007;56(5):1464-1477.

71. Brown DA, Rose JK. Sorting of GPI-anchored proteins to glycolipid enriched membrane subdomains during transport to the apical cell surface. Cell. 1992;68(3):533-544.

72. Pike LJ, Han X, Chung KN, Gross RW. Lipid rafts are enriched in arachidonic acid and plasmenylethanolamine and their composition is independent of caveolin-1 expression: a quantitative electrospray ionization/mass spectrometric analysis. Biochemistry. 2002;41(6):2075-2088.

73. Fridriksson EK, Shipkova PA, Sheets ED, Holowka D, Baird B, McLafferty FW. Quantitative analysis of phospholipids in functionally important membrane domains from RBL-2H3 mast cells using tandem high-resolution mass spectrometry. Biochemistry. 1999; 38(25):8056-8063.

74. Pike LJ. Rafts defined: a report on the Keystone Symposium on Lipid Rafts and Cell Function. J Lipid Res. 2006;47(7):1597-1598.

75. Rajendran L, Simons K. Lipid rafts and membrane dynamics. J Cell Sci. 2005;118(Pt6):1099-1102.
76. Hanzal-Bayer MF, Hancock JF. Lipid rafts and membrane traffic. FEBS Lett. 2007;581(11):209-104.

77. Sohn HW, Tolar P, Pierce SK. Membrane heterogeneities in the formation of B cell receptor-Lyn kinase microclusters and the immune synapse. J Cell Biol. 2008;182(2):367-379.

78. Lingwood D, Simons K. Lipid rafts as a membrane-organizing principle. Science. 2010;327(5961):46-50.

79. Li H, Ayer LM, Polyak MJ, et al. The CD20 calcium channel is localized to microvilli and constitutively associated with membrane rafts: antibody binding increases the affinity of the association through an epitope-dependent cross-linking-independent mechanism. J Biol Chem. 2004;279(19):19893-19901.

80. Setterblad N, Bécart S, Charron D, Mooney N. B cell lipid rafts regulate both peptide-dependent and peptide-independent APC-T cell interaction. J Immunol. 2004;173(3):1876-1886.

81. Xia M, Wang Q, Zhu H, et al. Lipid rafts regulate cellular CD40 receptor localization in vascular endothelial cells. Biochem Biophys Res Commun. 2007;361(3):768-774.

82. Oneyama C, Hikita T, Enya K, et al. The lipid raft-anchored adaptor protein Cbp controls the oncogenic potential of c-Src. Mol Cell. 2008; 30(4):426-436.

83. Spiegel $\mathrm{S}$. Insertion of ganglioside GM1 into rat glioma $\mathrm{C} 6$ cells renders them susceptible to growth inhibition by the B subunit of cholera toxin. Biochim Biophys Acta. 1988;969(3):249-256.

84. Fantini J, Maresca M, Hammache D, Yahi N, Delézay O. Glycosphingolipid (GSL) microdomains as attachment platforms for host pathogens and their toxins on intestinal epithelial cells: activation of signal transduction pathways and perturbations of intestinal absorption and secretion. Glycoconj J. 2000;17(3-4):173-179.

85. Hannun YA, Bell RM. Functions of sphingolipids and sphingolipid breakdown products in cellular regulation. Science. 1989; 243(4890):500-507.

86. Olivera A, Buckley NE, Spiegel S. Sphingomyelinase and cellpermeable ceramide analogs stimulate cellular proliferation in quiescent Swiss 3T3 fibroblasts. J Biol Chem. 1992;267(36):26121-26127.

87. Boyd RS, Jukes-Jones R, Walewska R, Brown D, Dyer MJ, Cain K. Protein profiling of plasma membranes defines aberrant signaling pathways in mantle cell lymphoma. Mol Cell Proteomics. 2009;8(7): $1501-1515$.

88. Meyer zum Büschenfelde C, Feuerstacke Y, Götze KS, Scholze K, Peschel C. GM1 expression of non-Hodgkin's lymphoma determines susceptibility to rituximab treatment. Cancer Res. 2008;68(13):5414-5422.

89. Daefler S, Krueger GR. Lack of dynamic lipid changes after binding of interleukin 2 in chronic lymphatic leukemia lymphocytes indicates defective transmembrane signaling. Anticancer Res. 1989;9(3): 743-748.

90. Daefler S, Krueger GR. Expression of proliferation and differentiation antigens in response to modulation of membrane fluidity in chronic lymphocytic leukemia lymphocytes. Anticancer Res. 1989;9(2):501-506.

91. Gouaze-Andersson V, Cabot MC. Glycosphingolipids and drug resistance. Biochim Biophys Acta. 2006;1758(12):2096-2103.

92. Consoli U, Santonocito A, Stagno F, et al. Multidrug resistance mechanisms in chronic lymphocytic leukaemia. Br J Haematol. 2002;116(4): 774-780.

93. Jamroziak K, Smolewski P, Cebula B, Szmigielska-Kaplon A, Darzynkiewicz Z, Robak T. Relation of P-glycoprotein expression with spontaneous in vitro apoptosis in B-cell chronic lymphocytic leukemia. Neoplasma. 2004;51(3):181-187.

94. Gerrard G, Butters TD, Ganeshaguru K, Mehta AB. Glucosylceramide synthase inhibitors sensitize CLL cells to cytotoxic agents without reversing P-gp functional activity. Eur J Pharmacol. 2009;609(1-3):34-39.

95. Malisan F, Testi R. GD3 ganglioside and apoptosis. Biochim Biophys Acta. 2002;1585(2-3):179-187.

96. Flores-Borja F, Kabouridis PS, Jury EC, Isenberg DA, Mageed RA. Altered lipid raft-associated proximal signaling and translocation of CD45 tyrosine phosphatase in B lymphocytes from patients with systemic lupus erythematosus. Arthritis Rheum. 2007;56(1):291-302. 
97. Flores-Borja F, Kabouridis PS, Jury EC, Isenberg DA, Mageed RA. Decreased Lyn expression and translocation to lipid raft signaling domains in B lymphocytes from patients with systemic lupus erythematosus. Arthritis Rheum. 2005;52(12):3955-3965.

98. Yanagi S, Sugawara H, Kurosaki M, Sabe H, Yamamura H, Kurosaki T. CD45 modulates phosphorylation of both autophosphorylation and negative regulatory tyrosines of Lyn in B cells. $J$ Biol Chem. 1996;271(48):30487-30492.

99. Clatworthy MR, Willcocks L, Urban B, et al. Systemic lupus erythematosus-associated defects in the inhibitory receptor FcgammaRIIb reduce susceptibility to malaria. Proc Natl Acad Sci U S A. 2007;104(17):7169-7174.

100. Kono H, Kyogoku C, Suzuki T, et al. FcgammaRIIB Ile232Thr transmembrane polymorphism associated with human systemic lupus erythematosus decreases affinity to lipid rafts and attenuates inhibitory effects on B cell receptor signaling. Hum Mol Genet. 2005;14(19): 2881-2892.

101. Coiffier B, Lepretre S, Pedersen LM, et al. Safety and efficacy of ofatumumab, a fully human monoclonal anti-CD20 antibody, in patients with relapsed or refractory B-cell chronic lymphocytic leukemia: a phase 1-2 study. Blood. 2008;111:1094-1100.

102. Goldenberg DM, Rossi EA, Stein R, et al. Properties and structurefunction relationships of veltuzumab (hA20), a humanized anti-CD20 monoclonal antibody. Blood. 2009;113(5):1062-1070.

103. Du J, Wang H, Zhong C, et al. Crystal structure of chimeric antibody C2H7 Fab in complex with a CD20 peptide. Mol Immunol. 2008;45: 2861-2868.
104. Robak T. GA-101, a third-generation, humanized and glyco-engineered anti-CD20 mAb for the treatment of B-cell lymphoid malignancies. Curr Opin Investig Drugs. 2009;10(6):588-596.

105. De Romeuf C, Dutertre CA, Le Garff-Tavernier M, et al. Chronic lymphocytic leukaemia cells are efficiently killed by an antiCD20 monoclonal antibody selected for improved engagement of FcgammaRIIIA/CD16. Br J Haematol. 2008;140(6):635-643.

106. Li M, Yan Z, Han W, Zhang Y. Mimotope vaccination for epitopespecific induction of anti-CD20 antibodies. Cell Immunol. 2006; 239(2):136-143.

107. Jain N, Wierda W, Ferrajoli A, et al. A phase 2 study of yttrium-90 ibritumomab tiuxetan (Zevalin) in patients with chronic lymphocytic leukemia. Cancer. 2009;115(19):4533-4539.

108. Cragg MS, Walshe CA, Ivanov AO, Glennie MJ. The biology of CD20 and its potential as a target for mAb therapy. Curr Dir Autoimmun 2005;8:140-174

109. Bornstein GG, Quéva C, Tabrizi M, et al. Development of a new fully human anti-CD20 monoclonal antibody for the treatment of B-cell malignancies. Invest New Drugs. 2009.

110. Li B, Shi S, Qian W, et al. Development of novel tetravalent antiCD20 antibodies with potent antitumor activity. Cancer Res. 2008;68: 2400-2408.

111. Rossi EA, Goldenberg DM, Cardillo TM, Stein R, Wang Y, Chang $\mathrm{CH}$. Novel designs of multivalent anti-CD20 humanized antibodies as improved lymphoma therapeutics. Cancer Res. 2008;68: 8384-8392.

\section{Publish your work in this journal}

OncoTargets and Therapy is an international, peer-reviewed, open access journal focusing on the pathological basis of all cancers, potential targets for therapy and treatment protocols employed to improve the management of cancer patients. The journal also focuses on the impact of management programs and new therapeutic agents and protocols on

\section{Dovepress}

patient perspectives such as quality of life, adherence and satisfaction. The manuscript management system is completely online and includes a very quick and fair peer-review system, which is all easy to use. Visit http://www.dovepress.com/testimonials.php to read real quotes from published authors. 